\title{
Production of recombinant 503 antigen of Leishmania infantum chagasi using cultivation in batch and fed-batch
}

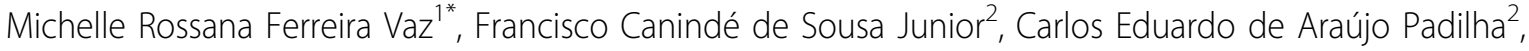 \\ Daniella Regina Arantes Martins ${ }^{3}$, Everaldo Silvino Santos², Gorete Ribeiro Macedo ${ }^{2}$ \\ From 5th Congress of the Brazilian Biotechnology Society (SBBIOTEC) \\ Florianópolis, Brazil. 10-14 November 2013
}

\section{Background}

Visceral leishmaniasis is an infecto-parasitarian disease caused by obligatory intracellular protozoa belonging to the genus Leishmania, and might be lethal since there is no precocious diagnosis and proper treatment. Despite the considerable effort, there is no effective and safe vaccine for human use [1]. Genetically modified microorganisms are used industrially in general for production of hormone, antibiotics and proteins. In the production of heterologous molecules, both the expression and the production step are important [2]. Therefore, the study of cultivation conditions in bioreactor plays an important role for the process viability of batch and fed-batch [3]. Thus, the aim of this work was to study strategies for production of the 503 antigen of Leishmania infantum chagasi using cultivation in batch and fed-batch.

\section{Methods}

The strain of E. coli expressing 503 antigen of Leishmania infantum chagasi was kindly provided by Dr. Mary Wilson (University of Iowa, USA) [1]. The clone was cultured in 2xTY medium supplemented with ampicillin and kanamycin. The cultivations were carried out using a bench bioreactor with a work volume of $1.5 \mathrm{~L}$, at frequency of agitation of $400 \mathrm{rpm}$ and constant output aeration of $1 \mathrm{vvm}$. The expression of the recombinant protein was induced by the addition of lactose to the cultivation medium at the final concentration of $10 \mathrm{~g} / \mathrm{L}$ [4]. Optimization of cultivation conditions of 503 antigen was performed in batch and fed-batch. Then, assays of the fractions were performed by Lowry method and

${ }^{1}$ Centro de Desenvolvimento Sustentável do Semiárido, Universidade Federal de Campina Grande, Sumé, PB, 58540-000, Brazil

Full list of author information is available at the end of the article electrophoresis, Biomass concentration was monitored by the dry weigh and the acetic acid concentration was assayed by high-performance liquid chromatography.

\section{Results and conclusions}

Fed-batch culture is one of the most performed strategies to reach high cell densities of E.coli and consequently high recombinant protein productivities. It was observed that to the cultivations in fed-batch, the agitation of $400 \mathrm{rpm}$ resulted increased the biomass of $2.5 \mathrm{~g} / \mathrm{L}$ to $11 \mathrm{~g} / \mathrm{L}$. It was observed the same behavior for the protein using both batch and fed-batch $(0.11 \mathrm{~g} / \mathrm{L})$. In the present study in the both processes it was not observed the inhibitory effect in the cellular growth as well as on the 503 protein expression. The highest acetic acid concentration was obtained at the agitation speed of $400 \mathrm{rpm}(0.2 \mathrm{~g} / \mathrm{L})$ that occurred during the first two hours of cultivation. However, this concentration was inferior to $0.9 \mathrm{~g} / \mathrm{L}$ that according to [5] have no inhibitory effect in the growth.

\section{Acknowledgements \\ The authors thank the CNPq (Conselho Nacional de Pesquisa e \\ Desenvolvimento Tecnológico) for the financial support and Dr. Mary E. Wilson (University of lowa, USA) for providing the microorganism strain. \\ Authors' details \\ ${ }^{1}$ Centro de Desenvolvimento Sustentável do Semiárido, Universidade Federal de Campina Grande, Sumé, PB, 58540-000, Brazil. ²Departamento de Engenharia Química, Universidade Federal do Rio Grande do Norte, Natal, RN, 59078-970, Brazil. ${ }^{3}$ Departamento de Biologia Celular e Genética, Universidade Federal do Rio Grande do Norte, Natal, RN, 59078-970, Brazil.}

Published: 1 October 2014

\section{References}

1. Martins DR, Jeronimo SM, Donelson JE, Wilson ME: Leishmania chagasi T-cell antigens identified through a double library screen. Infect Immun 2006, 74:6940-6948. 
2. Selvapandiyan A, Dey R, Gannavaram S, Lakhal-Naouar I, Duncan R, Salotra P, Nakhasi HL: Immunity to visceral leishmaniasis using genetically defined live-attenuated parasites. J TropMed 2012, 1:1-12.

3. Son YJ, Bae JY, Chong SH, Lee HS, Mo SH, Kim TY, Choe H: Expression, high cell density culture and purification of recombinant EC-SOD in Escherichia coli. Appl Biochem Biotechnol 2010, 162:1585-1598.

4. Carvalho RJ, Crabera-Crespo J, Tanizaki MM, Gonçalves VM: Development of production and purification processes of recombinant fragment of pneumococcal surface protein A in Escherichia coli using different carbon sources and chromatography sequences. Appl Microbiol Biotechnol 2012, 94:683-694.

5. Xue W, Fan D, Shang L, Zhu C, Ma X, Zhu X, Yu Y: Effects of acetic acid and its assimilation in fed-batch cultures of recombinant Escherichia coli containing human-like collagen cDNA. J Biosci Bioeng 2010, 109:257-261.

\section{doi:10.1186/1753-6561-8-S4-P186}

Cite this article as: Ferreira Vaz et al.: Production of recombinant 503 antigen of Leishmania infantum chagasi using cultivation in batch and fed-batch. BMC Proceedings 2014 8(Suppl 4):P186.

\section{Submit your next manuscript to BioMed Central} and take full advantage of:

- Convenient online submission

- Thorough peer review

- No space constraints or color figure charges

- Immediate publication on acceptance

- Inclusion in PubMed, CAS, Scopus and Google Scholar

- Research which is freely available for redistribution

Submit your manuscript at www.biomedcentral.com/submit
C Biomed Central 